\title{
Monoplegia after combined spinal epidural anesthesia
}

\section{Kombine spinal epidural anestezi sonrası gelişen monopleji}

\author{
Onur BALABAN, Yavuz GÜRKAN, Alparslan KUŞ, Kamil TOKER, Mine SOLAK
}

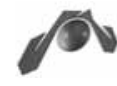

\begin{abstract}
Summary
Serious neurological complications after neuraxial block, including permanent neurological injury, are rare in contemporary anesthetic practice. We report a case of a 36 year old female undergoing a venous stripping operation under combined spinal epidural anesthesia (CSE). The CSE procedure was completed after a second attempt at the L4-L5 level and the surgery was completed uneventfully. After full recovery of motor block in the recovery room, the patient was discharged to the surgical ward. Epidural patient controlled analgesia with levobupivacine $0.125 \%$ and fentanyl $2 \mu \mathrm{g} / \mathrm{ml}$ was initiated. 10 hours after surgery, right lower limb sensory loss and monoplegia occurred. The epidural catheter was removed and normal MRI findings were noted. After one month of physical therapy treatment and two months follow up the patient was able to walk with the aid of a walking stick. We discuss factors that might have contributed to radiculopathy and neurotoxicity as a cause of neurologic deficit.
\end{abstract}

Key words: Combined spinal epidural; neurotoxicity; radiculopathy.

\begin{abstract}
Özet
Santral nöroaksiyel bloklarda, kalıcı sinir hasarı gibi ciddi nörolojik komplikasyonlar günümüz anestezi uygulamalarında nadiren görülür. Varis ameliyatı geçirecek olan 36 yaşında kadın hastaya kombine spinal epidural anestezi uygulandı. Anestezi uygulaması ve cerrabi işlem komplikasyonsuz tamamland. Alt ekstremitede motor blok çözülene kadar derlenme odasinda bekletilen basta, epidural hasta kontrollü anestezi başlatılarak cerrabi servise gönderlildi. Cerrabiden 10 saat sonra hastanın sağ tarafinda monopleji geliştiği görüldü. Epidural kateter çekildi. Hastanın lomber manyetik rezonans görüntülemesinde epidural hematoma rastlanmadı. Bir ay hastanede fizik tedavi ve iki aylı takip sonrası hasta, koltuk değneği ile yürüyebilir hale geldi. Bu olguda radikülopatiye neden olan faktörleri ve nörolojik defisit nedeni olarak nörotoksisiteyi tartışmak istedik.
\end{abstract}

Anahtar sözcükler: Kombine spinal epidural; nörotoksisite; radikülopati.

\section{Introduction}

Neurological deficits after central neuraxial blocks (CNB) are rarely reported in the literature. In determining the incidence of these complications usually we refer to a limited number of cases and retrospective studies. According to the results of these cases and retrospective studies, the incidence of serious neurological complications after CNBs is extremely low. But considering that there may be unreported cases, the incidence of neurological complications can be thought to be higher than known in the literature. Based on the case, we report the neurological complication in our patient, the following treatment done and we liked to discuss the cause of the neurological complication. 


\section{Case Report}

A 36-year-old female patient suffered from chronic pain with varicose veins at her lower extremities. She was admitted to cardiovascular surgery department of our hospital and venous stripping surgery was planned for treatment. Her medical history included hypertension, cholecystectomy and liver hydatid cyst operation. Before block performance $3 \mathrm{mg}$ midazolam and 50 microgram fentanyl was administered intravenously for sedation. Combined spinal epidural (CSE) anesthesia was administered using needle in needle technique at lateral decubitis position. In the first attempt, difficulty occured because of bone contact. At second attempt we removed the needle, palpated spinous processes and replaced the needle at same intervertebral space using a $27 \mathrm{G}$ Whitacre needle through an $18 \mathrm{G}$ Tuohy needle (B. Braun, Melsungen, Germany). The epidural space was located at $6 \mathrm{~cm}$ depth. A mixture of $10 \mathrm{mg}$ heavy bupivacaine and 25 microgram fentanyl was injected into the subarachnoid space via the spinal needle. A 20-gauge multiorifice catheter was threaded through the cranially directed tip of the epidural needle. Epidural catheter was threaded to $6 \mathrm{~cm}$ into the epidural space. At 75th minute of the operation, after two dermatomal segment regression, $5 \mathrm{ml}$ of $0.5 \%$ levobupivacaine was given epidurally. The operation was completed uneventfully (105 minutes). After the operation, the patient was transferred to the recovery room and was observed until motor block is resolved. Epidural $\mathrm{Pa}$ tient Controlled Analgesia (PCA) was prepared for post operative analgesia. $0.125 \%$ levobupivacaine with $2 \mathrm{mcg} / \mathrm{ml}$ fentanyl was prepared in $100 \mathrm{ml}$ $0.9 \% \mathrm{NaCl}$ solution. $5 \mathrm{ml}$ bolus dose, $20 \mathrm{ml}$ lock out time was set and limited to $30 \mathrm{ml}$ for $4 \mathrm{hrs}$. When the patient was visited by our pain nurse after 10 hours in surgical ward, it was seen that motor block developed at patient's right leg (Bromage score was 3 for light leg). Also sensory deficit from right ankle to thigh was noticed. The patient did not have sphincteric control and an urinary catheter was placed. PCA procedure was stopped $(25 \mathrm{ml}$ of local anesthetic and fentanyl combination had been given epidurally) and epidural catheter was removed without any difficulty. Lomber magnetic resonance imaging (MRI) scan was ordered. Results did not point epidural hematoma. Neurological examina- tion confirmed severe weakness of the right lower limb. Sphincter control recovered after 24 hours. The patient experienced severe pain radiating down to her right leg. Five days later electromyography (EMG) showed that the amplitude of tibial motor response was lower at right leg. 15 days later, control EMG showed L4-S2 radicular lesion. The patient continued further rehabilitation at our hospital. She had physical therapy for 4 weeks. Over the next 4 weeks, power gradually returned to normal in the right leg. There was improvement in sensation although she continued to complaining of pain in right leg, which persisted 2 months. After two months follow-up, she was able to ambulate with the aid of a walking stick. Her neurologic deficit fully recovered five months later.

\section{Discussion}

Because nerve injury after Regional Anesthesia (RA) is uncommon, prohibitively large numbers of patients are required for study in cohort to capture the incidence of neurological complications. Much of the available literature is restricted to retrospective reviews and surveys of anesthesiologists, both of which may be limited by under-reporting of complications. The rate of neurological complications may be under-estimated, because much of the source data relied on self-reporting from anesthesia providers rather than prospective controlled trials. [1] Many complications are known through case reports, and these rare events might not be evenly distributed within the patient population. Moen et al. ${ }^{[2]}$ reported that the overall frequency of severe neurological complications after spinal anesthesia was approximately 0.4:10.000. In fact, Moen et al. calculated the frequency of severe neurological complications after epidural anesthesia to be 2.8:10.000 when the obstetrical population is omitted, as opposed to 0.4:10.000 for obstetrical epidural anesthesia. Excluding obstetrics, Auroy et al. ${ }^{[3]}$ similarly found the incidence of major neurological complications related to Central Neuraxial Blockade (CNB) to be 3.4:10.000 compared to 0.6:10.000 for the obstetric population. CNBs were less risk for obstetric anesthesia (one complication for 140.450 CNBs) than for non-obstetric anesthetics (one severe complication for $67.581 \mathrm{CNBs}$ ). In obstetric anesthesia, complications are rarer as previously 
shown by Auroy. Associated risk factors for neurologic damage are paresthesia during needle/catheter placement, pain during injection of local anesthetic, or multiple attempts to perform a block. ${ }^{[4]}$ Direct trauma to the spinal cord during attempted epidural catheterization has been implicated as the possible cause of neurological complications. ${ }^{[5]}$ In the case described by Bromage and Benumof, ${ }^{[6]}$ an air bubble was identified within the cord of a patient who was left paraplegic after an attempted thoracic epidural using the loss of resistance to air technique to identify the epidural space. In our case postoperative MRI image showed a herniation at L5-S1 with compression to the thecal sac. Lumbar stenosis increases intracranial pressure during intraspinal administration and reduces local blood circulation, which could contribute to nerve root and spinal cord ischemia during CNBs. ${ }^{[7,8]}$ The presence of a narrow spinal canal could theoretically contribute to direct lesions during lumbar puncture by reducing nerve root freedom of movement and making puncture difficult. Lumbar epidural injection may also precipitate a severe and widespread lumbosacral poly-radiculopathy in the presence of pre-existing spinal stenosis. Wilkinson et al. ${ }^{[9]}$ proposed that the mechanism responsible for the early onset of neurological symptoms was direct penetration of the spinal cord during attempted epidural catheterization and subsequent injection of fluid into the substance of the cord, producing localized hydromyelia which was identified on the MRI scans of 3 cases. Spinothalamic sensory impairment and severe spontaneous pain over the affected area has persisted in all three patients. Inadvertent injection into a spinal root, during the initial subarachnoid injection or after placement of the epidural catheter, led to tracking of fluid up into the cord.

Experimental studies have indicated that all local anesthetic agents are potentially neurotoxic. Additional damage may therefore have occurred from the direct toxic effects of the active drugs within the cord. The placement of local anesthetic solutions into the epidural or subdural space as well as close to peripheral nerve fibers may cause neurotoxicity.

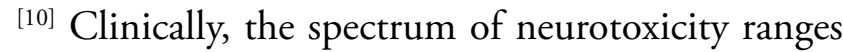
from patchy groin numbness and transient neurologic symptoms to irreversible cauda equina syndrome. Animal studies suggest that levobupivacaine and ropivacaine in high concentrations may damage neuronal structures, but clinical experience proves that their application is very well tolerated regarding neurotoxicity. ${ }^{[1]}$

MRI scanning did not point to spinal hematoma in our case. We removed the catheter immediately and could not verify its position at epidural space. Also myelogram could be useful to see catheter position. In our case catheter was threaded $6 \mathrm{~cm}$ into the epidural space. This could be the reason of migration of the catheter close to an intervertebral foramen or to a neural root which caused accumulation of local anesthetic to form a mass or to accumulate high concentrations of local anesthetic. This may be involved in neurological damage directly.

Suboptimal positioning of the epidural catheter is a common occurrence. Bridenbaugh et al. ${ }^{[12]}$ demonstrated with radiographic studies, that only approximately $12 \%$ of all epidural catheters directed in a cephalad direction actually threaded to the "hoped for" anatomic levels. They found that $21 \%$ of the catheters had a terminal loop, $48 \%$ coiled at the insertion site, and 5\% went in a caudad direction or migrated out through an intervertebral foramen.

Beilin et al. ${ }^{[13]}$ found that women in labor, who had multi-orifice epidural catheters threaded $5 \mathrm{~cm}$ into the epidural space through a cranially directed epidural needle orifice at the L2-L3 or L3-L4 intervertebral space, had the highest incidence of successful analgesia with $0.25 \%$ bupivacaine, as compared to women with catheters threaded 3 or $7 \mathrm{~cm}$ into the epidural space. In addition, women in the $5-\mathrm{cm}$ group had a lower epidural anesthesia complication rate as compared to those in the $7 \mathrm{~cm}$ group and equal to those in the $3 \mathrm{~cm}$ group. In our case we threaded epidural catheter $6 \mathrm{~cm}$ into the epidural space. Greater length of catheter insertion increases the likelihood of unilateral sensory analgesia or intravenous canulation and shorter lengths may risk unintentional dislodgement. ${ }^{[14]}$

The frequency of severe, permanent neurological complications related to epidural catheterization, based on prospective and retrospective studies, seems to be extremely low. Standard tools of evidence-based medicine such as randomized con- 
trolled trials, meta-analysis, and prospective human studies rarely exist. In this case local anesthetic toxicity seems to be the reason of neurologic deficit and catheter threaded longer than necessary into the epidural space might have contributed to toxic effect of local anesthetic.

\section{Conflict-of-interest issues regarding the authorship or article: None declared.}

\section{Peer-rewiew: Externally peer-reviewed.}

\section{References}

1. Brull R, McCartney CJ, Chan VW, El-Beheiry H. Neurological complications after regional anesthesia: contemporary estimates of risk. Anesth Analg 2007;104(4):965-74.

2. Moen V, Dahlgren N, Irestedt L. Severe neurological complications after central neuraxial blockades in Sweden 19901999. Anesthesiology 2004;101(4):950-9.

3. Auroy Y, Benhamou D, Bargues L, Ecoffey C, Falissard B, Mercier $\mathrm{FJ}$, et al. Major complications of regional anesthesia in France: The SOS Regional Anesthesia Hotline Service. Anesthesiology 2002;97(5):1274-80.

4. Horlocker TT, Abel MD, Messick JM Jr, Schroeder DR. Small risk of serious neurologic complications related to lumbar epidural catheter placement in anesthetized patients. Anesth Analg 2003;96(6):1547-52.

5. Barontini F, Conti P, Marello G, Maurri S. Major neurological sequelae of lumbar epidural anesthesia. Report of three cases. Ital J Neurol Sci 1996;17(5):333-9.

6. Bromage PR, Benumof JL. Paraplegia following intracord injection during attempted epidural anesthesia under general anesthesia. Reg Anesth Pain Med 1998;23(1):104-7.

7. Jacob AK, Borowiec JC, Long TR, Brown MJ, Rydberg CH, Wass CT. Transient profound neurologic deficit associated with thoracic epidural analgesia in an elderly patient. Anesthesiology 2004;101(6):1470-1.

8. de Sèze $M$, de Sèze $M$, Joseph PA, Wiart $L$, Nguyen PV, Barat $M$. Functional prognosis of paraplegia due to cord ischemia: a retrospective study of 23 patients. Rev Neurol (Paris) 2003;159(11):1038-45.

9. Wilkinson PA, Valentine A, Gibbs JM. Intrinsic spinal cord lesions complicating epidural anaesthesia and analgesia: report of three cases. J Neurol Neurosurg Psychiatry 2002;72(4):537-9.

10. Cox B, Durieux ME, Marcus MA. Toxicity of local anaesthetics. Best Pract Res Clin Anaesthesiol 2003;17(1):111-36.

11. Zink W, Graf BM. The toxicity of local anesthetics: the place of ropivacaine and levobupivacaine. Curr Opin Anaesthesiol 2008;21(5):645-50. doi: 10.1097/ACO.0b013e32830c214c.

12. Bridenbaugh LD, Moore DC, Bagdi P, Bridenbaugh PO. The position of plastic tubing in continuous-block techniques: an x-ray study of 552 patients. Anesthesiology 1968;29:1047-9.

13. Beilin Y, Bernstein HH, Zucker-Pinchoff B. The optimal distance that a multiorifice epidural catheter should be threaded into the epidural space. Anesth Analg 1995;81(2):301-4.

14. D'Angelo R, Berkebile BL, Gerancher JC. Prospective examination of epidural catheter insertion. Anesthesiology 1996;84(1):88-93. 